\title{
Faith and Spirituality - Palliative Cares and Life Quality for Cancer Patients: Information Archeology with Statistics Table as from a Systematic Review

\section{Abstract}

Background: The faith and spirituality in palliative cares started to be used in medical community in the last decade of the XX century. The faith is known as a synonym of trust and hope being considered a positive emotion which helps the individual to enlarge tolerance, moral, growing creativity and building of new expectations. And the spirituality is related to psychological experiences of religiousness, associated individual idea. Such themes are inserted in the assistance to the palliative cancer patient.

Objective: Evaluate current evidences related to faith themes and spirituality when used in palliative cares and its effects facing the life quality of these patients, aiming to systematize them.

Method: Talks about a systematic qualitative review of faith and spirituality themes, whereas makes it possible to summarize researches already concluded and obtain conclusions from a theme of interest. The clinical research question, which was built through PICOS strategies, was "How can the faith and spirituality facilitate situations which promote life quality to patients who are experiencing palliative care?" The bibliographic search occurred in February/2015, in PubMed/MEDLINE and Scopus databases, using indexed papers from January 2002 to December 2014.

Results and discussion: 319 articles were obtained, being 67 eligible articles for final phase. The data was extracted in a standardized way, through a table of characterization and addressed to five categories, the current study pointed a scientific contribution as from faith and spirituality themes from the emotions anatomy knowledge covering how the authors could work with patients' positive emotions starting from faith and spirituality communication, such themes which permeated all
Regiane Teixeira Silveira1,2, Modesto Leite Rolim Neto ${ }^{1,3}$

1 Posgraduate Program In Health Science Faculty of Medicine of $A B C$, Santo André, São Paulo, Brazil.

2 Department Oncology Clinic, Hospital Israelita Albert Einstein, São Paulo, São Paulo, Brazil.

3 Faculty of Medicine, Federal University of Cariri, UFCA, Barbalha, Ceará, Brazil.

Contact information:

Modesto Leite Rolim Neto.

झ modestorolim@yahoo.com.br 
categories worked in this study considering at a time an improvement of physiological and psychological symptoms, of immunologic and social relations during the palliative treatment. [Conclusion]: the studies involved in this review refer to the human factor which is related directly to the patient care, in special health teams, needs to be trained to deal with care concepts about the patient faith and spirituality. Therefore, trainings are needed for these professionals enabling them to deal with this so fragile population which requires therapeutic techniques well applied and respect for each one's individuality.

\section{Keywords}

Faith. Spirituality.

Palliative Care. Neoplasms.

\section{Introduction}

The World Health Organization (WHO) highlights the cancer as being one of the most non-transmissible deceases responsible for the population illness profile change, estimating that, in 2030, it's expected 27 million incident cancer, 17 million cancer deaths and 75 million living people, annually, suffering from cancer. The biggest effect of this increase will happen in low income countries, as a result, considering cancer a global health problem [1, 2].

Thinking of diagnosed population and cancer treatment, a group of scientists of São Paulo's Medicine Regional Council (CREMESP), 2002, described that most of the deceases are incurable, thus, the treatment aims its evolution control and turns this illness chronic. They use the word "cure" as a truth slightly worked in Medicine. Within this theme holding that the patient becomes out of "cure possibility" reflects two situations; every patient should be under palliative care, or it would only be addressed to palliative care according to medical team criteria when they state that the patient is living his last life hours. The second situation implies in a misconception, thinking that palliative care can be summarized only to the provided care to the final phase of life, when there is nothing else to be done [3].

The palliative approach teamwork added to a healing treatment is the most viable possibility, to develop palliative actions in the diagnoses phase and in treatment, evaluating that as the decease progresses, and the treatment doesn't provide any expected improvement to the patient and therapeutics possibilities get scarce, the palliative care grow in meaning, coming up a real necessity to interventions in the symptoms control not only biologics but also emotional ones, so that the patient and their relatives understand the decease process [3]. Said that, in the advanced phase of a decease the patient and their relatives analyze that the death process is getting closer, they start to understand that the palliative care is able to provide procedures, medicaments, and approaches for physical and emotional well-being until the end of the life [3].

The applicability of palliative care will happen when the diagnoses is presented, when there is a health problem facing moment associated to the death risk, dealing with sorrow prevention and relief throughout premature identification, impeccable evaluation about the pain treatment and other spiritual, psychosocial and physical problems [4]. In this perspective, it can be a "mistake "thinking that palliative care is a therapeutics to be applied only when there is an imminent death risk. To be diagnosed with cancer the patient longs for a treatment provided by a multi-professional team, at this moment the patient is submitted to a huge emotional stress. Situation which should be evaluated and stu- 
died cautiously, as studies refer to treatment effectiveness depending on the patient emotional state. As soon as the patient is diagnosed he refers to a brief death reaction moment, starting to elaborate unconsciously the grieving process $[3,5]$. When referring to the grieving, it is related to the loss of physical health, at this first moment the patient denies the diagnoses, the problem existence or the situation. He seems not to believe in what is being informed about, tries to forget it, not to think, and also searches for evidences or arguments for the new reality [4].

According to Harvard studies developed by Vaillant [6], limbic experiences of faith (internal or external), are so remarkable, unforgettable and real as any other deep emotional experience, the limbic experiences produce the same sensation as inner calmness, pleasure and hope feelings (waiting for something better), taking moments of faith and spirituality discussions as refuge, support and a venue where the patient can trust to process and express his conflicts, fears, fantasies, and anguish related to the decease, to the treatment or his death $[6,7]$.

The patients who are experiencing the palliative care have the need to be heard and have better quality of life. In this context the palliative care definition by Canadian Palliative Care Association Standards Committee (1995) and WHO (2002), considering the patients in their spiritual needs [8,9]. Facing this, faith and spirituality have been identified being intrinsically linked to the treatment, providing to the patient a reflection opportunity, self-perception as an individual and a beginning of strategy elaboration to cope with this new life condition.

According to Veit and Castro [7] the religious and spiritual factors have been associated to various aspects of adequacy to the diagnoses and cancer treatment, pointing its importance for the patient's health and recovery. Being the faith described as trust and safety, having its origin in three sources: a conscious one (neocortical) and two are unconscious (limbic), these sources depict the cognitive certainty need, the social need of community and emotional need of trust $[6,7]$. This study chose to amplify the knowledge about the need of faith and spirituality, bringing its relation to oncologic patient life quality in palliative care [8].

\section{Method}

It aims a qualitative systematic review about faith and spirituality themes, since it enables summarizing the already concluded researches and reach conclusions from a topic of interest. A well done systematic review demands the same standard of rigor, clarity and replication used in primary studies. Said that, a Cochrane Handbook Collaboration guide adaptation was used for qualitative analyses, $2001[10,11]$. For this paper, PICOS strategy was chosen (participants/patients, intervention, comparison, "outcome" and study kind of "Stude") [12]. It is a strategy which enables a guiding research questioning for review: how can faith and spirituality facilitate situations that promote the patients' life quality who are experiencing palliative care?, with determiners for exclusion and inclusion criteria, driving the study and the organization of logics reasoning $[10,11]$. In this paper, the study did not use the C component (comparison) of PICOS strategy, once there isn't stablished standardized treatment.

The search for the material was widely done using descriptors Medical Subject Headings (MeSH): "neoplasm", "spirituality", "palliative care", suitable for index the articles from Medical Literature Analysis and Retrieval System Online (MEDLINE/PubMed) and Scopus database. Apart from the key-word "faith", once that, even not composing a MeSH descriptor, it is often used to describe studies of this review theme. Search strategy correlated the descriptors as follows: 1) "faith" AND "palliative care" AND "neoplasms"; 2) "spirituality" AND "palliative care" AND "neoplasms". The search occurred in February/2015, with indexed studies in the last twelve years (2002-2014), considering that the redefinition of palliative care by WHO dates of 2002 [8]. 
The papers selection occurred mainly through titles and reviews analyses. After identifying the articles, they were independently evaluated by the authors, considering the following inclusion criteria: (1) Studies which evaluated the faith/spirituality roles as a facilitator and/or strategy to obtain oncologic patients life quality experiencing the palliative care process; (2) Articles which had in the title or in the abstract at least a descriptor combination in the search strategy; (3) Considered articles that referred to oncologic patients in palliative care; (4) There wasn't restriction due to the published articles language, when there wasn't domain (English, Portuguese and Spanish languages) article translation was required to translators. In order to avoid idiom bias; (5) Prospective or retrospective studies of observational feature (analytical or descriptive), clinic and qualitative trials, containing terms Faith and spirituality in the process to evaluate palliative care and life quality being psychological well-being and /or adaptation, symptoms control. Exclusion criteria: editorials, case story, brief comments, digest, News or letter linked to scientific papers and thesis, monographs, essays, systematic review articles, congress productions, (synopsis, expanded synopsis, or complete texts), chapters of books and books. The articles that didn't present available access to the full text on CAPES database (Coordination for Student Improvement in Academic Research), and that were not sent by authors after being required by email.

\section{Results}

The characterization data of scientific production about Faith and spirituality in oncologic patients is presented in absolute frequency with statistics percentages (Table 1). The article selection process was well elaborated, as PICOS refined strategy was used and inclusion criteria (Figure 1).

Table 1. Identified Studies according to Electronic database. Santo André, 2015.

\begin{tabular}{l|c|c|c|c|} 
& \multicolumn{2}{|c|}{$\begin{array}{c}\text { Identified Studies by } \\
\text { electronic search }\end{array}$} & \multicolumn{2}{|c|}{$\begin{array}{l}\text { Late gestational } \\
\text { age ( } \mathbf{2 3} \text { weeks) }\end{array}$} \\
\hline Database & \multicolumn{3}{|c|}{ Obtained Studies } & \multicolumn{2}{|c|}{ Included Studies } \\
\hline & $\mathrm{N}$ & $\%$ & $\mathrm{~N}$ & $\%$ \\
\hline Scopus & 142 & $44,5 \%$ & 55 & $82,1 \%$ \\
\hline $\begin{array}{l}\text { Pubmed/ } \\
\text { Medline }\end{array}$ & 177 & $55,5 \%$ & 12 & $17,90 \%$ \\
\hline Total & 319 & $100 \%$ & 67 & $100 \%$ \\
\hline
\end{tabular}

Figure 1: Flowchart of the selection process stages of included studies in the present review. Santo André, 2015.

Potencially relevant studies identified in the the initial search in eletronic databases
\[ N=319 \]
$\begin{gathered}\text { Duplicated References (removed) } \\ N=115\end{gathered} \quad \begin{gathered}\text { References for eligibility analysis } \\ N=204\end{gathered}$

\section{Inclusion criteria}

1. Observational (analitical or descriptive) prospective or retrospective studies, clinical and qualitative trials;

2. Faith/spirituality/palliative cares;

3. Oncologic pacients;

4. Original texts with full access online or sent by the author
136 references excluded after heading and abstract analysis:

a. Did not meet the inclusion criteria $(N=105)$;

b. Were not avaiable in full text or were not sent by the author after email contact $(\mathrm{N}=31)$

\section{References with the full text analised for elegibility}

$$
N=67
$$

Studies included in the review

$$
\mathrm{N}=67
$$


For the duplicated studies removal was used the criteria to keep the base study of data which contained the most detailed study. Thus, after detailed reading, it was chosen to keep the studies that were in the Scopus electronic database which brought fifty-five $(82,1 \%)$ of eligible publication for this review.

Here are presented the identified studies about faith and spirituality in oncologic patients who ex- perienced palliative care. Sixty seven articles were identified related to the proposed theme, considered eligible ones for the final phase. The data was extracted in a standardized way of filtered and evidenced studies, developed characterization tables (Table 2, Table 3, Table 4, Table 5).

Table 2. Characteristics of database Scopus studies $(N=4)$ - descriptors (faith and palliative care and neoplasms), Santo André, 2015.

\begin{tabular}{|c|c|c|c|c|c|}
\hline Author & Title & Periodic & Year & Categories & Main Findings \\
\hline $\begin{array}{l}\text { Rosenzweig, } \\
\text { M.Q., } \\
\text { Wiehagen, T., } \\
\text { Brufsky, A., } \\
\text { Arnold, R. [13] }\end{array}$ & $\begin{array}{l}\text { Challenges of } \\
\text { illness in metastatic } \\
\text { breast cancer: } \\
\text { A low-income } \\
\text { African American } \\
\text { perspective }\end{array}$ & $\begin{array}{l}\text { Palliative } \\
\text { and } \\
\text { Supportive } \\
\text { Care }\end{array}$ & 2009 & $\begin{array}{l}\text { Control } \\
\text { symptoms } \\
\text { and quality } \\
\text { of life }\end{array}$ & $\begin{array}{l}\text { Study with focus groups where faith issues, } \\
\text { hope and progressive loss. But the black } \\
\text { low-income American women expressed } \\
\text { solely greater physical and social suffering } \\
\text { and more uncertainty about treatment } \\
\text { goals and treatment than other racial and } \\
\text { economic groups outlined. Significance } \\
\text { of the results: There are many points in } \\
\text { common for the challenges of the disease. }\end{array}$ \\
\hline $\begin{array}{l}\text { Koffman, J., } \\
\text { Morgan, M., } \\
\text { Edmonds, } \\
\text { P., Speck, P., } \\
\text { Higginson, I.J. } \\
\text { [14] }\end{array}$ & $\begin{array}{l}\text { Cultural meanings } \\
\text { of pain: A qualitative } \\
\text { study of Black } \\
\text { Caribbean and } \\
\text { White British } \\
\text { patients with } \\
\text { advanced cancer }\end{array}$ & $\begin{array}{l}\text { Palliative } \\
\text { Medicine }\end{array}$ & 2008 & $\begin{array}{l}\text { Control } \\
\text { symptoms } \\
\text { and quality } \\
\text { of life }\end{array}$ & $\begin{array}{l}\text { Pain as a "test of faith" which refers to the } \\
\text { confirmation and strengthening of religious } \\
\text { belief, and pain as a "punishment" that } \\
\text { was associated with wrongdoing. These } \\
\text { meanings influenced patients in extent and } \\
\text { were able to accommodate her anguish. }\end{array}$ \\
\hline $\begin{array}{l}\text { Fatone, A.M., } \\
\text { Moadel, A.B., } \\
\text { Foley, F.W., } \\
\text { Fleming, M., } \\
\text { Jandorf, L. [15] }\end{array}$ & $\begin{array}{l}\text { Urban voices: } \\
\text { The quality-of-life } \\
\text { experience among } \\
\text { women of color with } \\
\text { breast cancer }\end{array}$ & $\begin{array}{l}\text { Palliative } \\
\text { and } \\
\text { Supportive } \\
\text { Care }\end{array}$ & 2007 & $\begin{array}{l}\text { Control } \\
\text { symptoms } \\
\text { and quality } \\
\text { of life }\end{array}$ & $\begin{array}{l}\text { Themes were identified and classified into } \\
\text { six domains: physical (pain and nausea), } \\
\text { psychological (sadness, irritability, cognitive } \\
\text { (memory problems), sex (decrease of desire), } \\
\text { social / functional (financial stress, social } \\
\text { anxiety) and existential spiritual ( increasing } \\
\text { faith, spiritual coping). The patients saw faith } \\
\text { as an important way of coping with breast } \\
\text { cancer. Reports that expressed positive } \\
\text { changes in their faith after diagnosis. }\end{array}$ \\
\hline $\begin{array}{l}\text { Hirai, K., } \\
\text { Miyashita, } \\
\text { M., Morita, } \\
\text { T., Sanjo, M., } \\
\text { Uchitomi, Y. } \\
\text { [16] }\end{array}$ & $\begin{array}{l}\text { Good death } \\
\text { in Japanese } \\
\text { caC10:J10ncer care: } \\
\text { A qualitative study }\end{array}$ & $\begin{array}{l}\text { Journal of } \\
\text { Pain and } \\
\text { Symptom } \\
\text { Manage- } \\
\text { ment }\end{array}$ & 2006 & $\begin{array}{l}\text { Control } \\
\text { symptoms } \\
\text { and quality } \\
\text { of life }\end{array}$ & $\begin{array}{l}\text { Maintaining hope, not prolong life, helping } \\
\text { others, future control and not be aware of } \\
\text { death, appreciating others, Maintenance } \\
\text { pride, and have faith. The most frequently } \\
\text { mentioned category was "Freedom from } \\
\text { pain or physical / psychological symptoms" } \\
\text { and less frequently was "Have faith." }\end{array}$ \\
\hline
\end{tabular}


Table 3. Characterization of the database Scopus studies ( $N=51$ ) - descriptors (Spirituality and palliative care and neoplasms), Santo André, 2015.

\begin{tabular}{|c|c|c|c|c|c|}
\hline Author & Title & Periodic & Year & Categories & Main Findings \\
\hline $\begin{array}{l}\text { Asgeirsdottir } \\
\text { et.al. [17] }\end{array}$ & $\begin{array}{l}\text { In the shadow of death: } \\
\text { existential and spiritual concerns } \\
\text { among persons receiving } \\
\text { palliative care. }\end{array}$ & $\begin{array}{l}\text { The journal of } \\
\text { pastoral care e } \\
\text { counseling }\end{array}$ & 2014 & $\begin{array}{l}\text { Spirituality and } \\
\text { Coping }\end{array}$ & $\begin{array}{l}\text { The findings show existential and spiritual aspects as interconnected and } \\
\text { integral part of daily life of the participants. He concludes with a call for a } \\
\text { better understanding of these phenomena in the context of palliative care. }\end{array}$ \\
\hline $\begin{array}{l}\text { King, et.al. } \\
{[18]}\end{array}$ & $\begin{array}{l}\text { Spiritual beliefs near the end of } \\
\text { life: A prospective cohort study } \\
\text { of people with cancer receiving } \\
\text { palliative care }\end{array}$ & Pshyco-Oncology & 2013 & $\begin{array}{l}\text { Symptoms } \\
\text { control, quality } \\
\text { of life and } \\
\text { spirituality }\end{array}$ & $\begin{array}{l}\text { The results suggest that while religious and spiritual beliefs may marginally } \\
\text { increase the coping with the disease and approaching death, they do not } \\
\text { affect levels of anxiety and depression in patients with advanced cancer. }\end{array}$ \\
\hline $\begin{array}{l}\text { Douglas, S.L., } \\
\text { Daly, B.J. [19] }\end{array}$ & $\begin{array}{l}\text { The impact of patient quality of } \\
\text { life and spirituality upon caregiver } \\
\text { depression for those with } \\
\text { advanced cancer }\end{array}$ & $\begin{array}{l}\text { Palliative and } \\
\text { Sipportive Care }\end{array}$ & 2013 & $\begin{array}{l}\text { Coping and } \\
\text { quality of life }\end{array}$ & $\begin{array}{l}\text { The spirituality of patients is critical to your coping and adjusting to cancer. } \\
\text { It is this aspect of the overall quality of life of patients that mediates the } \\
\text { improvement of the relationship between their caregivers. It is considered } \\
\text { the spiritual welfare the most powerful intervention for depression } \\
\text { caregiver may be attending the patient spiritual anguish. }\end{array}$ \\
\hline $\begin{array}{l}\text { Skeath, et.al. } \\
\text { [20] }\end{array}$ & $\begin{array}{l}\text { The nature of life-transforming } \\
\text { changes among cancer survivors }\end{array}$ & $\begin{array}{l}\text { Qualitative Health } \\
\text { Research }\end{array}$ & 2013 & $\begin{array}{l}\text { Coping and } \\
\text { quality of life }\end{array}$ & $\begin{array}{l}\text { Discovery of unanticipated personal skills and resources, and that has } \\
\text { become very useful in dealing with other challenges beyond cancer. This } \\
\text { caused an increase in capacity and personnel resources "life changing" } \\
\text { instead of being limited to substantially reduce the problems with cancer. } \\
\text { Support Intervention for facilitated positive change processes can reduce } \\
\text { suffering and improve psychosocial outcomes and positive spiritual for } \\
\text { patients. }\end{array}$ \\
\hline Yang et.al. [21] & $\begin{array}{l}\text { A comprehensive approach in } \\
\text { hospice shared care in Taiwan: } \\
\text { Nonelderly patients have more } \\
\text { physical, psychosocial and spiritual }\end{array}$ & $\begin{array}{l}\text { Kaohsing Journal of } \\
\text { Medical Sciences }\end{array}$ & 2013 & $\begin{array}{l}\text { Spirituality and } \\
\text { coping }\end{array}$ & $\begin{array}{l}\text { Patients under the age of } 60 \text { years have more physical, psychosocial and } \\
\text { spiritual suffering. This study suggests that professional practitioners should } \\
\text { provide intensive care for terminally ill patients. }\end{array}$ \\
\hline
\end{tabular}




\begin{tabular}{|c|c|c|c|c|c|}
\hline Author & Title & Periodic & Year & Categories & Main Findings \\
\hline $\begin{array}{l}\text { Wong et.al. } \\
{[22]}\end{array}$ & $\begin{array}{l}\text { Factors influencing health related } \\
\text { quality of life in cancer patients } \\
\text { with bone metastases }\end{array}$ & $\begin{array}{l}\text { Journal of Palliative } \\
\text { Medicine }\end{array}$ & 2013 & $\begin{array}{l}\text { Symptoms } \\
\text { control, quality } \\
\text { of life and } \\
\text { spirituality }\end{array}$ & $\begin{array}{l}\text { This study identified basic gender factors, performance status, and } \\
\text { histology as primary determinants of health-realed quality of life (HRQOL) } \\
\text { in patients with bone metastases. Further study focusing on current } \\
\text { treatment (chemotherapy, radiation therapy and bisphosphonates) and } \\
\text { spiritual well-being can identify additional factors affecting HRQoL. }\end{array}$ \\
\hline Ho et.al. [23] & $\begin{array}{l}\text { Living and dying with dignity in } \\
\text { Chinese society: Perspectives of } \\
\text { older palliative care patients in } \\
\text { Hong Kong }\end{array}$ & Age and Ageing & 2013 & $\begin{array}{l}\text { Coping and } \\
\text { Cultural Issues }\end{array}$ & $\begin{array}{l}\text { It showed that the dignity, spirituality and resilience are guidelines for } \\
\text { palliative care interventions in Chinese culture. }\end{array}$ \\
\hline $\begin{array}{l}\text { Balboni et. al. } \\
{[24]}\end{array}$ & $\begin{array}{l}\text { Provision of spiritual support to } \\
\text { patients with advanced cancer } \\
\text { by religious communities and } \\
\text { associations with medical care at } \\
\text { the end of life }\end{array}$ & $\begin{array}{l}\text { JAMA International } \\
\text { Medicine }\end{array}$ & 2013 & $\begin{array}{l}\text { Spirituality } \\
\text { coping and } \\
\text { quality of life }\end{array}$ & $\begin{array}{l}\text { Patients with high spiritual support from religious communities ( } 43 \%) \text { were } \\
\text { less likely to receive palliative care. With lower chances of terminal phase } \\
\text { spread in an intensive care unit. }\end{array}$ \\
\hline $\begin{array}{l}\text { Keall, RM, } \\
\text { Butow, PN, } \\
\text { Steinhauser, } \\
\text { KE, Clayton, } \\
\text { JM [26] }\end{array}$ & $\begin{array}{l}\text { Nurse-facilitated preparation and } \\
\text { life completion interventions are } \\
\text { acceptable and feasible in the } \\
\text { australian palliative care setting: } \\
\text { Results from a phase } 2 \text { trial }\end{array}$ & Cancer Nursing & 2013 & $\begin{array}{l}\text { Spirituality } \\
\text { coping and } \\
\text { quality of life }\end{array}$ & $\begin{array}{l}\text { Patients reported intervention and evaluation to be acceptable and } \\
\text { viable global and be received positively, although with no significant } \\
\text { improvements in measures of "meaning and peace" and "preparation for } \\
\text { the end of life. }\end{array}$ \\
\hline $\begin{array}{l}\text { Vivat et. al. } \\
{[27]}\end{array}$ & $\begin{array}{l}\text { Cross-cultural development } \\
\text { of the EORTC QLQ-SWB36: A } \\
\text { stand-alone measure of spiritual } \\
\text { wellbeing for palliative care } \\
\text { patients with cancer }\end{array}$ & Palliative Medicine & 2013 & $\begin{array}{l}\text { Coping and } \\
\text { Cultural Issues }\end{array}$ & $\begin{array}{l}\text { Identified key issues for the spiritual well-being in multiple cultural } \\
\text { contexts, and that the items are understandable and consistent in all } \\
\text { languages. }\end{array}$ \\
\hline
\end{tabular}




\begin{tabular}{|c|c|c|c|c|c|}
\hline Author & Title & Periodic & Year & Categories & Main Findings \\
\hline $\begin{array}{l}\text { Nakau et.al. } \\
{[28]}\end{array}$ & $\begin{array}{l}\text { Spiritual care of cancer patients } \\
\text { by integrated medicine in urban } \\
\text { green space: A pilot study }\end{array}$ & $\begin{array}{l}\text { The Journal of } \\
\text { Science and Healing }\end{array}$ & 2013 & $\begin{array}{l}\text { Symptom control } \\
\text { and spirituality }\end{array}$ & $\begin{array}{l}\text { Improving program quality of life and reduction of fatigue associated with } \\
\text { cancer. In addition, some aspects of the psychological state were improved } \\
\text { and activity of natural killer cells was increased. It is indicated that the } \\
\text { integrative medicine held in a green environment is potentially useful for } \\
\text { emotional and spiritual well-being of cancer patients }\end{array}$ \\
\hline $\begin{array}{l}\text { Balboni et.al. } \\
{[29]}\end{array}$ & $\begin{array}{l}\text { Why is spiritual care infrequent } \\
\text { at the end of life? spiritual care } \\
\text { perceptions among patients, } \\
\text { nurses, and physicians and the } \\
\text { role of training }\end{array}$ & $\begin{array}{l}\text { Journal of Clinical } \\
\text { Oncology }\end{array}$ & 2013 & $\begin{array}{l}\text { Spirituality and } \\
\text { quality of life }\end{array}$ & $\begin{array}{l}\text { Patients, nurses and doctors visualize spiritual care as an important } \\
\text { component, appropriate and beneficial terminal care. Spiritual care is rarity } \\
\text { may be mainly due to lack of training, suggesting that training of this type } \\
\text { of care is fundamental to this clientele. }\end{array}$ \\
\hline $\begin{array}{l}\text { Rawdin, B et } \\
\text { al }[30]\end{array}$ & $\begin{array}{l}\text { The relationships among hope, } \\
\text { pain, psychological distress, and } \\
\text { spiritual well-being in oncology } \\
\text { outpatients }\end{array}$ & $\begin{array}{l}\text { Journal of Palliative } \\
\text { Medicine }\end{array}$ & 2013 & $\begin{array}{l}\text { Symptom control } \\
\text { and spirituality }\end{array}$ & $\begin{array}{l}\text { Hope has a stronger correlation with psycho-spiritual factors that the } \\
\text { experience of pain. }\end{array}$ \\
\hline Ho et.al. [32] & $\begin{array}{l}\text { Certain bio-psychosocial-spiritual } \\
\text { problems associated with dyspnea } \\
\text { among advanced cancer patients } \\
\text { in Taiwan }\end{array}$ & $\begin{array}{l}\text { Supportive Care in } \\
\text { Cancer }\end{array}$ & 2012 & $\begin{array}{l}\text { Symptom } \\
\text { control, coping } \\
\text { and spirituality }\end{array}$ & $\begin{array}{l}\text { The spiritual and psychological preparations make patient has } \\
\text { improvement in signs and symptoms such as dyspnea and anxiety. }\end{array}$ \\
\hline $\begin{array}{l}\text { Samuelson, } \\
\text { BT, Fromme, } \\
\text { EK, Thomas, } \\
\text { CR [33] }\end{array}$ & $\begin{array}{l}\text { Changes in Spirituality and Quality } \\
\text { of Life in Patients Undergoing } \\
\text { Radiation Therapy }\end{array}$ & $\begin{array}{l}\text { Journal of Alternative } \\
\text { and Complementary } \\
\text { Medicine }\end{array}$ & 2012 & $\begin{array}{l}\text { Spirituality and } \\
\text { quality of life }\end{array}$ & $\begin{array}{l}\text { Spirituality related to physical well-being, psychological women with breast } \\
\text { cancer incidence ranging between ages, but with significant sample of } \\
\text { improving quality of life. }\end{array}$ \\
\hline $\begin{array}{l}\text { McClean, S.et } \\
\text { al. [34] }\end{array}$ & $\begin{array}{l}\text { The healing and spiritual } \\
\text { properties of music therapy at a } \\
\text { cancer care center }\end{array}$ & $\begin{array}{l}\text { The Journal Of } \\
\text { Alternative And } \\
\text { Complementary } \\
\text { Medicine }\end{array}$ & 2012 & Spirituality & $\begin{array}{l}\text { The authors consider the applicability of wider schemes that attempt to } \\
\text { define and explore the role and the importance of spirituality. }\end{array}$ \\
\hline
\end{tabular}




\section{Author}

Kang et.al. [35]

\section{Title}

Addressing the religious and spiritual needs of dying patients by healthcare staff in Korea: Patient perspectives in a multireligious Asian country

Spencer, RJ Ray, A., Pirl,

Clinical correlates of suicida thoughts in patients with

WF, Prigerson, advanced cancer HG [36]

\section{Vallurupalli} et.al. [37]

The Role of Spirituality and Religious Coping in the Quality of Life of Patients With Advanced Cancer Receiving Palliative Radiation Therapy

Balboni et.al. Support of cancer patients' spiritual needs and associations with medical care costs at the end of life

Winkelman et.al. [39]

The relationship of spiritual concerns to the quality of life of advanced cancer patients: Preliminary findings

Fallah, R. et al Integrating spirituality into a [40] group psychotherapy program

\section{Periodic}

Pshyco-Oncology

2012

Americam Journal of

\section{Journal of Suportive} Oncology

Quality of life Coping and Cultural Issues

\section{Cancer} and quality of life

Journal of Palliative Medicine

Iranian Journal of for women surviving from breast cancer
Cancer Prevention
Coping and Symptoms control
Coping and quality of life quality of life

\section{Main Findings}

Although patients whose spiritual and religious needs were addressed by the health team showed significantly better quality of life, those needs have not been addressed in a significant proportion of patients, especially those who were not religious or were admitted to palliative care centers non- religious. Strategies should be developed to ensure that spiritual care is provided to all patients with terminal cancer, regardless of religious background of the patient

Spirituality interventions minimizing physical suffering can offer the promise of reducing suicidal thoughts in this risk group. For patients with advanced cancer report suicidal thoughts are more likely to meet the criteria for post-traumatic stress disorder and panic disorder, feel unsupported.

Patients who received palliative radiotherapy who had religious and spiritual support showed improvement of coping with the disease contributing to a better quality of life. These results highlight the importance of spiritual care in the treatment of advanced cancer.

Application of spiritual and religious care, improve quality of life and minimizing symptoms, generating lower costs for the healthcare system.

Spiritual care is associated with improved QoL in patients with advanced cancer, they view the attention to spirituality as an important part of medical care. These data reinforce the importance of spiritual care role in palliative cancer management.

Spiritual treatment, is a potentially beneficial intervention to increase mental strength among those suffering from breast cancer. Therefore, it seems necessary to consider it as an important element incomprehensible treatment, plans, and palliative care and support. 


\begin{tabular}{|c|c|c|c|c|c|}
\hline Author & Title & Periodic & Year & Categories & Main Findings \\
\hline $\begin{array}{l}\text { Trinkaus et.al. } \\
{[41]}\end{array}$ & $\begin{array}{l}\text { Spirituality and use of } \\
\text { complementary therapies for } \\
\text { cure in advanced cancer }\end{array}$ & Psycho-oncology & 2011 & $\begin{array}{l}\text { Spirituality and } \\
\text { quality of life }\end{array}$ & $\begin{array}{l}\text { Use of complementary therapies considered was associated with increased } \\
\text { faith and a decrease of the existential welfare. }\end{array}$ \\
\hline $\begin{array}{l}\text { Delgado-Guay } \\
\text { et.al. [42] }\end{array}$ & $\begin{array}{l}\text { Spirituality, religiosity, and } \\
\text { spiritual pain in advanced cancer } \\
\text { patients }\end{array}$ & $\begin{array}{l}\text { Journal of Pain } \\
\text { and Symptom } \\
\text { Management }\end{array}$ & 2011 & $\begin{array}{l}\text { Symptom control } \\
\text { and spirituality }\end{array}$ & $\begin{array}{l}\text { The vast majority of patients with advanced cancer receiving palliative care } \\
\text { considered themselves spiritual and religious. Spiritual pain was common } \\
\text { and was associated with lower religiosity self perception and spiritual } \\
\text { quality of life. }\end{array}$ \\
\hline Hui et.al. [43] & $\begin{array}{l}\text { The frequency and correlates of } \\
\text { spiritual distress among patients } \\
\text { with advanced cancer admitted } \\
\text { to an acute palliative care unit }\end{array}$ & $\begin{array}{l}\text { Americam Journal } \\
\text { of Hospice Palliative } \\
\text { Medicine }\end{array}$ & 2011 & $\begin{array}{l}\text { Symptom control } \\
\text { and spirituality }\end{array}$ & $\begin{array}{l}\text { The study says the link between the physical, psychosocial and spiritual } \\
\text { personality with the important implication that an interdisciplinary team } \\
\text { approach is required to meet the complex needs of patients in palliative } \\
\text { care and their families. Minimizing the physical suffering and grief }\end{array}$ \\
\hline $\begin{array}{l}\text { Balboni et.al. } \\
{[44]}\end{array}$ & $\begin{array}{l}\text { "It depends": Viewpoints of } \\
\text { patients, physicians, and nurses } \\
\text { on patient-practitioner prayer in } \\
\text { the setting of advanced cancer }\end{array}$ & $\begin{array}{l}\text { Journal of Pain } \\
\text { and Symptom } \\
\text { Management }\end{array}$ & 2011 & $\begin{array}{l}\text { Symptom control } \\
\text { and quality of } \\
\text { life }\end{array}$ & $\begin{array}{l}\text { The use of patient-doctor prayer in palliative cancer scenario revealed } \\
\text { the potential benefits of prayer, critical attitudes, positive attitudes, the } \\
\text { majority of patients and professionals view patient-professional prayer, at } \\
\text { least from time to time appropriate in the advanced cancer setting, and } \\
\text { Most patients see prayer as spiritually supportive and beneficial }\end{array}$ \\
\hline $\begin{array}{l}\text { Bergman, } \\
\text { J., Fink, A., } \\
\text { Kwan, L., } \\
\text { Maliski, S., } \\
\text { Litwin, MS [45] }\end{array}$ & $\begin{array}{l}\text { Spirituality and end-of-life care } \\
\text { in disadvantaged men dying of } \\
\text { prostate cancer }\end{array}$ & $\begin{array}{l}\text { World Journal of } \\
\text { Urology }\end{array}$ & 2011 & $\begin{array}{l}\text { Quality of life } \\
\text { and spirituality }\end{array}$ & $\begin{array}{l}\text { Men with higher spirituality tended to increased use of hospice, which } \\
\text { suggests that they redirected the focus of its curative care to palliative } \\
\text { goals. }\end{array}$ \\
\hline $\begin{array}{l}\text { Kandasamy, } \\
\text { A., } \\
\text { Chaturvedi, } \\
\text { SK, Desai, } \\
\text { G.[46] }\end{array}$ & $\begin{array}{l}\text { Spirituality, distress, depression, } \\
\text { anxiety, and quality of life in } \\
\text { patients with advanced cancer }\end{array}$ & $\begin{array}{l}\text { Source of the } \\
\text { Document Indian } \\
\text { Journal of Cancer }\end{array}$ & 2011 & $\begin{array}{l}\text { Symptom } \\
\text { control, quality } \\
\text { of life and } \\
\text { spirituality }\end{array}$ & $\begin{array}{l}\text { This study suggests that spiritual well-being is an important component } \\
\text { of quality of life of patients with advanced cancer, and is closely related } \\
\text { to the physical and psychological symptoms of distress. It should be } \\
\text { adequately addressed and appropriately in palliative care settings. }\end{array}$ \\
\hline $\begin{array}{l}\text { Leung et.al. } \\
{[47]}\end{array}$ & $\begin{array}{l}\text { Can a good death and quality of } \\
\text { life be achieved for patients with } \\
\text { terminal cancer in a palliative } \\
\text { care unit? }\end{array}$ & $\begin{array}{l}\text { Journal of Palliative } \\
\text { Medicine }\end{array}$ & 2010 & $\begin{array}{l}\text { Symptom } \\
\text { control, quality } \\
\text { of life and } \\
\text { spirituality }\end{array}$ & $\begin{array}{l}\text { Comprehensive palliative care (spiritual care), patients with terminal cancer } \\
\text { can have good quality of life and experience a good death, even with low } \\
\text { survival rate. }\end{array}$ \\
\hline
\end{tabular}




\begin{tabular}{|c|c|c|c|c|c|}
\hline Author & Title & Periodic & Year & Categories & Main Findings \\
\hline $\begin{array}{l}\text { Pituskin et.al. } \\
\text { [48] }\end{array}$ & $\begin{array}{l}\text { Multidisciplinary team } \\
\text { contributions within a dedicated } \\
\text { outpatient palliative radiotherapy } \\
\text { clinic: A prospective descriptive } \\
\text { study }\end{array}$ & $\begin{array}{l}\text { International } \\
\text { Journal of Radiation } \\
\text { Oncology Biology } \\
\text { Physics }\end{array}$ & 2010 & $\begin{array}{l}\text { Symptoms } \\
\text { control and } \\
\text { quality of life }\end{array}$ & $\begin{array}{l}\text { Patients with bone metastases can feel pain, fatigue and decreased } \\
\text { mobility. Various medications for pain control are often required, each } \\
\text { with side effects. Although palliative radiotherapy to be effective in } \\
\text { reducing pain, additional interventions supportive care can not be } \\
\text { neglected. }\end{array}$ \\
\hline $\begin{array}{l}\text { Kamper, R., } \\
\text { Van Cleve, } \\
\text { L., Savedra, } \\
\text { M.[49] }\end{array}$ & $\begin{array}{l}\text { Children With Advanced Cancer: } \\
\text { Responses to a Spiritual Quality of } \\
\text { Life Interview }\end{array}$ & $\begin{array}{l}\text { Journal for Specilists } \\
\text { in pediatric Nursing }\end{array}$ & 2010 & Spírituality & $\begin{array}{l}\text { The children's answers were mostly related to their parents. Seventy- } \\
\text { eight percent of respondents said that they did something to "feel close } \\
\text { to God." They prayed for Children "normal sense" (59\%) and related } \\
\text { concerns (31\%). }\end{array}$ \\
\hline $\begin{array}{l}\text { Mishra et.al. } \\
\text { [50] }\end{array}$ & $\begin{array}{l}\text { Psychosocial concerns in patients } \\
\text { with advanced cancer: An } \\
\text { observational study at regional } \\
\text { cancer centre, India }\end{array}$ & $\begin{array}{l}\text { American Journal of } \\
\text { Hospice and Palliative } \\
\text { Medicine }\end{array}$ & 2010 & $\begin{array}{l}\text { Spirituality and } \\
\text { Quality of life }\end{array}$ & $\begin{array}{l}\text { Attention to psychosocial health needs and spiritual needs of cancer } \\
\text { patients is an integral part of an effective palliative, though less commonly } \\
\text { expressed but are strongly felt by cancer patients. It is therefore } \\
\text { recommended that all doctors and health care providers must meet the } \\
\text { psychosocial health needs as part of their routine }\end{array}$ \\
\hline $\begin{array}{l}\text { Collette, N., } \\
\text { Pascual, A. } \\
{[51]}\end{array}$ & $\begin{array}{l}\text { Dos casos de sufrimiento tratados } \\
\text { con arteterapia: Una aproximación } \\
\text { simbólica y espiritual | }\end{array}$ & Medicine Palliative & 2010 & $\begin{array}{l}\text { Symptom } \\
\text { control, quality } \\
\text { of life and } \\
\text { spirituality }\end{array}$ & $\begin{array}{l}\text { It was observed that the result of the art therapy has contributed to the } \\
\text { improved quality of life and communication. These lead to increased } \\
\text { family welfare. Consequently, the art therapy is valued positively by the } \\
\text { interdisciplinary team. }\end{array}$ \\
\hline $\begin{array}{l}\text { Breitbart et. } \\
\text { al. [52] }\end{array}$ & $\begin{array}{l}\text { Meaning-centered group } \\
\text { psychotherapy for patients } \\
\text { with advanced cancer: A pilot } \\
\text { randomized controlled trial }\end{array}$ & Psycho-oncology & 2010 & $\begin{array}{l}\text { Symptom control } \\
\text { and spirituality }\end{array}$ & $\begin{array}{l}\text { It showed that psychotherapy groups resulted in significantly greater } \\
\text { improvements in spiritual well-being and a sense of meaning. Gains } \\
\text { treatment were even more substantial (based on estimates of such great } \\
\text { effect) the second follow-up evaluation. Improvements in anxiety and } \\
\text { desire for death were also significant (and increased over time). Concluding } \\
\text { that this type of therapy seems to be a potentially beneficial intervention for } \\
\text { emotional and spiritual suffering of patients at the end of life. }\end{array}$ \\
\hline $\begin{array}{l}\text { Rinaldis, M., } \\
\text { Pakenham, KI, } \\
\text { Lynch, BM, } \\
\text { Aitken, JF [53] }\end{array}$ & $\begin{array}{l}\text { Development, confirmation, } \\
\text { and validation of a measure of } \\
\text { Coping with Colorectal Cancer: } \\
\text { A longitudinal investigation }\end{array}$ & Psycho-oncology & 2009 & $\begin{array}{l}\text { Quality of life } \\
\text { and spirituality }\end{array}$ & $\begin{array}{l}\text { Exploratory and confirmatory factor analyzes revealed eight subscales } \\
\text { mainly empirically distinct: Positive Perceptual change, religion / spirituality, } \\
\text { rumination, acceptance, humor, palliative, seeking social support and } \\
\text { sanitation lifestyle. }\end{array}$ \\
\hline
\end{tabular}




\begin{tabular}{|c|c|c|c|c|c|}
\hline Author & Title & Periodic & Year & Categories & Main Findings \\
\hline $\begin{array}{l}\text { Rodin et.al. } \\
{[54]}\end{array}$ & $\begin{array}{l}\text { Pathways to distress: The } \\
\text { multiple determinants of } \\
\text { depression, hopelessness, and } \\
\text { the desire for hastened death in } \\
\text { metastatic cancer patients }\end{array}$ & $\begin{array}{l}\text { Social Science and } \\
\text { Medicine }\end{array}$ & 2009 & $\begin{array}{l}\text { Symptom } \\
\text { control, quality } \\
\text { of life and } \\
\text { spirituality }\end{array}$ & $\begin{array}{l}\text { Holistic approach to palliative care in patients with metastatic cancer } \\
\text { aimed at physical, psychological and spiritual works to prevent and treat } \\
\text { anxiety and symptoms in patients with advanced disease. }\end{array}$ \\
\hline $\begin{array}{l}\text { Mystakidou } \\
\text { et.al. [55] }\end{array}$ & $\begin{array}{l}\text { Predictors of spirituality at the } \\
\text { end of life }\end{array}$ & $\begin{array}{l}\text { Canadian Family } \\
\text { Physician }\end{array}$ & 2008 & $\begin{array}{l}\text { Symptom } \\
\text { control, quality } \\
\text { of life and } \\
\text { spirituality }\end{array}$ & $\begin{array}{l}\text { The demographic and clinical characteristics and stronger hopelessness } \\
\text { seemed to have statistically significant relationships with spirituality. } \\
\text { Interventions to improve spiritual well-being of patients should take these } \\
\text { relationships into account. }\end{array}$ \\
\hline $\begin{array}{l}\text { Steinhauser } \\
\text { et.al. [56] }\end{array}$ & $\begin{array}{l}\text { Do preparation and life } \\
\text { completion discussions improve } \\
\text { functioning and quality of life } \\
\text { in seriously ill patients? Pilot } \\
\text { randomized control trial }\end{array}$ & $\begin{array}{l}\text { Journal of Palliative } \\
\text { Medicine }\end{array}$ & 2008 & $\begin{array}{l}\text { Quality of life } \\
\text { and spirituality }\end{array}$ & $\begin{array}{l}\text { Participants in the discussion active intervention showed improvements in } \\
\text { functional status, anxiety, depression, and preparation for the end of life. }\end{array}$ \\
\hline $\begin{array}{l}\text { Koffman, J., } \\
\text { Morgan, M., } \\
\text { Edmonds, } \\
\text { P., Speck, P., } \\
\text { Higginson, [58] }\end{array}$ & $\begin{array}{l}\text { "I know he controls cancer": } \\
\text { The meanings of religion among } \\
\text { Black Caribbean and White British } \\
\text { patients with advanced cancer }\end{array}$ & $\begin{array}{l}\text { Social Science and } \\
\text { Medicine }\end{array}$ & 2008 & $\begin{array}{l}\text { Symptom } \\
\text { control, quality } \\
\text { of life and } \\
\text { spirituality }\end{array}$ & $\begin{array}{l}\text { Three main themes emerged from accounts of patients: the ways in which } \\
\text { patients believed religion and belief in God helped them to understand } \\
\text { cancer; how you felt their faith and the emotional and practical support } \\
\text { given by church communities helped to live with the physical and } \\
\text { psychological effects of their disease and its progression. }\end{array}$ \\
\hline $\begin{array}{l}\text { Mystakidou } \\
\text { et.al. [59] }\end{array}$ & $\begin{array}{l}\text { Demographic and clinical } \\
\text { predictors of spirituality in } \\
\text { advanced cancer patients: A } \\
\text { randomized control study }\end{array}$ & $\begin{array}{l}\text { Journal of Clinical } \\
\text { Nursing }\end{array}$ & 2008 & $\begin{array}{l}\text { Symptom } \\
\text { control, quality } \\
\text { of life and } \\
\text { spirituality }\end{array}$ & $\begin{array}{l}\text { The study recognized by the patients 'demographic characteristics and } \\
\text { health, such as female gender, advanced age, years of schooling, state } \\
\text { performance and radiotherapy contributes to the prediction of patients' } \\
\text { spiritual beliefs and attitudes of relevance to clinical practice. Meeting } \\
\text { the spiritual needs of palliative care between the needs afraid to die, } \\
\text { losses were crucial aspects of psychological functioning, especially when } \\
\text { considering certain demographic and clinical characteristics. }\end{array}$ \\
\hline
\end{tabular}




\section{Author}

Wijk, H.,

Grimby, A.

[60]

Title

Document Needs of elderly

patients in palliative care

Periodic

American Journal

Palliative Medicine

Ando, M.,

Tsuda, A.,

Morita, T. [61]
Life review interviews on the spiritual well-being of terminally

ill cancer patients. of Hospice and
Supportive Care in

Cancer

\section{Year}

2008

Categories

Symptom

control, quality

of life and

spirituality

2007 Symptom

control, quality

of life and

spirituality

\section{Main Findings}

Elimination of physical pain was classified as the main need half of the patients. Only when the pain was eliminated or absent made other important needs (psychological, social, spiritual) appear frequently.

Life review interviews can be effective in improving spiritual well-being of patients with terminal cancer. Potential predictors of success of treatment are "positive outlook on life," "pleasure in daily activities and good human relations" and a "balanced assessment of life", while of treatment failure are "worries about the future caused by disease", conflict in family relationships and confrontation of practical problems.

The results of this study confirm that the involvement and scales of spiritual beliefs is an instrument with satisfactory psychometric properties and is a research tool valid for spirituality in patients with advanced cancer.

\section{of Hospice and}

Palliative Medicine

PARPA, E.,

patients

2006

Symptom

control, quality

of life and

spirituality

Smyrnioti, $M$

Mako, C.,

Galek, K.,

Poppito, SR

Spiritual pain among patients

Journal of Palliative

2006

Quality of life with advanced cancer in palliative Medicine care

Considering both the universality of spiritual pain and the multifaceted nature of pain, it was proposed that when patients report the experience of pain, plus the complexity of the phenomena involved in the treatment and spiritual pain can be considered a contributing factor to the failure of the treatment. The authors say that the spiritual pain is not treated as both hinder the recovery will contribute to the overall suffering of the patient.

\section{Supportive Care in 2005 Quality of life}

Cancer

and spirituality

Spiritual experiences can have a big impact on the physical and emotional well-being and facilitate the process of dying. Music therapy, psychotherapy and spiritual assistance provide essential methods for psycho-oncology and palliative care. A holistic and interdisciplinary approach to help patients in their suffering complex is required.

in Switzerland

McClain- Belief in an afterlife, spiritual

Jacobson et.al. well-being and end-of-life despair

General Hospital

Psychiatry
2004 Quality of life
The results indicated that the belief in the afterlife was associated with lower levels of end of life of despair (death wish, hopelessness and suicidal thoughts), but was not associated with levels of depression or anxiety. The authors concluded that spirituality has a much more powerful effect on psychological functioning than beliefs about the afterlife. 


\begin{tabular}{|c|c|c|c|c|c|}
\hline Author & Title & Periodic & Year & Categories & Main Findings \\
\hline $\begin{array}{l}\text { Kawa et.al. } \\
\text { [66] }\end{array}$ & $\begin{array}{l}\text { Distress of inpatients with } \\
\text { terminal cancer in Japanese } \\
\text { palliative care units: From the } \\
\text { viewpoint of spirituality }\end{array}$ & $\begin{array}{l}\text { Supportive Care in } \\
\text { Cancer }\end{array}$ & 2003 & $\begin{array}{l}\text { Symptom } \\
\text { control, quality } \\
\text { of life and } \\
\text { spirituality }\end{array}$ & $\begin{array}{l}\text { Three categories were evaluated: anguish due to the difference } \\
\text { between the current situation and how the individual wanted to live, } \\
\text { as the individual wanted to die, and desire of the individual to maintain } \\
\text { relationships with others. The aspirations causing the difference was } \\
\text { interpreted from the spiritual point of view as "anchors in life" for Japanese } \\
\text { patients with terminal cancer. }\end{array}$ \\
\hline $\begin{array}{l}\text { McClain, C.S., } \\
\text { Rosenfeld, B., } \\
\text { Breitbart, W. } \\
{[67]}\end{array}$ & $\begin{array}{l}\text { Effect of spiritual well-being on } \\
\text { end-of-life despair in terminally-ill } \\
\text { cancer patients }\end{array}$ & Lancet & 2003 & Spirituality & Spiritual welfare provides protection against despair end of life. \\
\hline
\end{tabular}

Table 4. Characteristics of database studies Pubmed / Medline ( $N=8)$ - descriptors (Spirituality and palliative care and neoplasms), Santo André, 2015.

\begin{tabular}{|c|c|c|c|c|c|}
\hline Author & Title & Periodic & Year & Categories & Main Findings \\
\hline $\begin{array}{l}\text { Osborne et.al. } \\
\text { [68] }\end{array}$ & $\begin{array}{l}\text { Understanding what matters } \\
\text { most to people with multiple } \\
\text { myeloma: a qualitative study of } \\
\text { views on quality of life }\end{array}$ & BMC Cancer & 2014 & Quality of life & $\begin{array}{l}\text { The main topics important to the QoL were biological state, treatment } \\
\text { factors, symptoms, participation in coping and Spirituality activity. } \\
\text { Symptoms had an indirect effect on Qo L, affecting only general QoL } \\
\text { is impacted on activity and participation, emotional state or supporting } \\
\text { factors and spirituality. }\end{array}$ \\
\hline $\begin{array}{l}\text { Vilalta A, Valls } \\
\text { J, Porta J, } \\
\text { Viñas J. [69] }\end{array}$ & $\begin{array}{l}\text { Evaluation of spiritual needs of } \\
\text { patients with advanced cancer in } \\
\text { a palliative care unit. }\end{array}$ & $\begin{array}{l}\text { Journal Palliative } \\
\text { Medicine }\end{array}$ & 2014 & $\begin{array}{l}\text { Quality of life } \\
\text { and spirituality }\end{array}$ & $\begin{array}{l}\text { The spiritual needs emerged as the most important issue for patients: their } \\
\text { need to be recognized as a person until the end of his life and his need to } \\
\text { know the truth about his illness. The least within the spirituality was the } \\
\text { continuity and the afterlife; to get rid of obsessions; to achieve freedom } \\
\text { from guilt and be able to forgive others; and the need for reconciliation and } \\
\text { feel forgiven by others. Concluding that when patients knew the truth about } \\
\text { their disease and they were treated with dignity and have better coping. }\end{array}$ \\
\hline
\end{tabular}




\begin{tabular}{|c|c|c|c|c|c|}
\hline Author & Title & Periodic & Year & Categories & Main Findings \\
\hline $\begin{array}{l}\text { Trevino KM, } \\
\text { Archambault } \\
\text { E, Schuster JL, } \\
\text { Hilgeman MM, } \\
\text { Moye J. [70] }\end{array}$ & $\begin{array}{l}\text { Religiosity and spirituality in } \\
\text { military veteran cancer survivors: } \\
\text { a qualitative perspective. }\end{array}$ & $\begin{array}{l}\text { Journal of } \\
\text { Psychosocial } \\
\text { Oncology }\end{array}$ & 2011 & Quality of life & $\begin{array}{l}\text { Palliative care can be difficult and religion and spirituality provide resources } \\
\text { to deal with the challenges of survival. This study sheds light on the role of } \\
\text { religion and spirituality in coping physical and psychological experience of } \\
\text { cancer survivors. }\end{array}$ \\
\hline $\begin{array}{l}\text { Rose et.al. } \\
{[71]}\end{array}$ & $\begin{array}{l}\text { Patterns of adaptation in } \\
\text { patients living long term with } \\
\text { advanced cancer. }\end{array}$ & Psyco-Oncology & 2010 & $\begin{array}{l}\text { Symptom } \\
\text { control and } \\
\text { quality of life }\end{array}$ & $\begin{array}{l}\text { The current findings suggest that psycho-spiritual adaptation. In this } \\
\text { study, it is not uniform but is characterized by heterogeneous trajectories. } \\
\text { The results contribute to the development of better hypotheses about the } \\
\text { processes of adaptation in long-term survivors with advanced cancer and } \\
\text { to identify potential subgroups of higher risk for poor outcomes. }\end{array}$ \\
\hline $\begin{array}{l}\text { Alcorn et.al. } \\
{[72]}\end{array}$ & $\begin{array}{l}\text { "If God wanted me yesterday, } \\
\text { I wouldn't be here today": } \\
\text { religious and spiritual themes } \\
\text { in patients' experiences of } \\
\text { advanced cancer. }\end{array}$ & $\begin{array}{l}\text { Journal of Palliative } \\
\text { Medicine }\end{array}$ & 2010 & Quality of life & $\begin{array}{l}\text { Religion and / or often spiritual play a key role in the wellbeing of the } \\
\text { patient maintenance. }\end{array}$ \\
\hline $\begin{array}{l}\text { Mystakidou } \\
\text { et.al. [73] }\end{array}$ & $\begin{array}{l}\text { Exploring the relationships } \\
\text { between depression, } \\
\text { hopelessness, cognitive status, } \\
\text { pain, and spirituality in patients } \\
\text { with advanced cancer. }\end{array}$ & $\begin{array}{l}\text { Archive Psychiatr } \\
\text { Nursing }\end{array}$ & 2007 & $\begin{array}{l}\text { Symptom } \\
\text { control and } \\
\text { quality of life }\end{array}$ & $\begin{array}{l}\text { Significant associations were found between interference of physical pain } \\
\text { and the joy of life and despair, as well as among the worst pain and pain } \\
\text { interference items such as depression and cognitive status. Significant } \\
\text { correlations were found between despair, depression, and cognitive } \\
\text { condition. These results demonstrate the physical, psychological and } \\
\text { cognitive cancer patients. }\end{array}$ \\
\hline $\begin{array}{l}\text { Noguchi et.al. } \\
\text { [74] }\end{array}$ & $\begin{array}{l}\text { Spiritual needs in cancer patients } \\
\text { and spiritual care based on } \\
\text { logotherapy. }\end{array}$ & $\begin{array}{l}\text { Support Care } \\
\text { Cancer }\end{array}$ & 2006 & $\begin{array}{l}\text { Quality of life } \\
\text { and spirituality }\end{array}$ & $\begin{array}{l}\text { The Japanese people generally have no strict and definite religious faith } \\
\text { and have a tendency to rely on morality and ethics in their own mind } \\
\text { rather than to put importance on religious feeling to believe in "God", } \\
\text { which is outside their own mind. }\end{array}$ \\
\hline $\begin{array}{l}\text { Luhrs et.al. } \\
{[75]}\end{array}$ & $\begin{array}{l}\text { Pilot of a pathway to improve } \\
\text { the care of imminently dying } \\
\text { oncology inpatients in a } \\
\text { Veterans Affairs Medical Center. }\end{array}$ & $\begin{array}{l}\text { Journal Pain } \\
\text { Sympton Manage }\end{array}$ & 2005 & $\begin{array}{l}\text { Quality of life } \\
\text { and spirituality }\end{array}$ & $\begin{array}{l}\text { Palliative patients, reviewing care goals, have their wishes respected, } \\
\text { evaluation of re life control symptoms, spiritual welfare and improvement } \\
\text { of family relationships. }\end{array}$ \\
\hline
\end{tabular}


Table 5. Characteristics of database studies Pubmed / Medline ( $N=4)$ - descriptors (Faith and palliative care and neoplasms), Santo André, 2015.

\begin{tabular}{|c|c|c|c|c|c|}
\hline Author & Title & Periodic & Year & Categories & Main Findings \\
\hline $\begin{array}{l}\text { Paiva et.al. } \\
\text { [76] }\end{array}$ & $\begin{array}{l}\text { A pilot study addressing the } \\
\text { impact of religious practice on } \\
\text { quality of life of breast cancer } \\
\text { patients during chemotherapy. }\end{array}$ & J Relig Health & 2013 & $\begin{array}{l}\text { Quality of life } \\
\text { and spirituality }\end{array}$ & $\begin{array}{l}\text { It was to investigate whether religious practice can change the quality } \\
\text { of life (QOL) of patients during chemotherapy. QOL questionnaire and } \\
\text { religious practice mark was evaluated in a group of patients at different } \\
\text { times (before, during and after chemotherapy). Acceptance of body } \\
\text { image was positively correlated to religious practice and the activity to } \\
\text { be praying. This preliminary study suggests the importance of religion to } \\
\text { cope with treatment. }\end{array}$ \\
\hline $\begin{array}{l}\text { McConigley } \\
\text { et.al. [77] }\end{array}$ & $\begin{array}{l}\text { The diagnosis and treatment } \\
\text { decisions of cancer patients in } \\
\text { rural Western Australia. }\end{array}$ & Cancer Nurs. & 2011 & $\begin{array}{l}\text { Quality of life } \\
\text { and spirituality }\end{array}$ & $\begin{array}{l}\text { Four themes were identified to describe the cancer experience in rural } \\
\text { patients. The first three themes, diagnostic experiences and referral, } \\
\text { treatment, and manage their own care. The final overall theme, Implicit } \\
\text { Faith, described the level of trust that patients have in the health system, } \\
\text { often despite the delays and inconveniences. }\end{array}$ \\
\hline $\begin{array}{l}\text { Utne et.al. } \\
\text { [78] }\end{array}$ & $\begin{array}{l}\text { The relationship between } \\
\text { hope and pain in a sample of } \\
\text { hospitalized oncology patients. }\end{array}$ & $\begin{array}{l}\text { Palliative Support } \\
\text { Care }\end{array}$ & 2008 & $\begin{array}{l}\text { Quality of life } \\
\text { and spirituality }\end{array}$ & $\begin{array}{l}\text { The higher levels of hope in cancer patients with pain reflect a "change } \\
\text { response" in the assessment of patients regarding hope. The fact that } \\
\text { significant relationships were found between the scores scale of hope and } \\
\text { the more psychosocial interference scores, suggesting that hope can be } \\
\text { more related to psychosocial effects on pain than in their physical effects. }\end{array}$ \\
\hline $\begin{array}{l}\text { Sharf BF, } \\
\text { Stelljes LA, } \\
\text { Gordon HS. } \\
\text { [79] }\end{array}$ & $\begin{array}{l}\text { A little bitty spot and I'm a big } \\
\text { man': patients' perspectives on } \\
\text { refusing diagnosis or treatment } \\
\text { for lung cancer. }\end{array}$ & Phyco-oncology & 2005 & Spirituality & $\begin{array}{l}\text { Complaints about the communication with doctors, the health system } \\
\text { discontinuities, and the impact of social support. Implications for clinical } \\
\text { communication include increased confidence to deliver bad news, } \\
\text { understanding the source of resistance to the recommendations, and } \\
\text { discuss palliative care. }\end{array}$ \\
\hline
\end{tabular}




\section{Discussion}

The clarity of this treatment associated to life quality will depend on each individual life story, their beliefs and values about themselves and about the current situation. What emphasizes the need of this study. The PICOS strategy made possible to meet the targets and evaluate evidences about faith and spirituality benefits associated to life quality. Thus, bibliographic search involved two database Pubmed/MEDLINE and Scopus, both with wide coverage that allowed retrieving database filed studies and posteriorly turned into characterization tables for writing and discussing this study.

During the process of articles selection were found three 2002 indexed articles, however they didn't fit the proposed inclusion criteria for this study, described perspectives of cancer terminal patient relatives, review articles about spiritual and existential issues, such as meaning, hope and spirituality in general, in palliative patients and the third excluded article was about the spirituality and religious impact in severity depressive symptoms in a sample of terminal cancer and AIDS (Acquired Immunodeficiency Syndrome) patients. Because it is a focus in oncologic patients our pattern considers studies from 2003 on (Figure 2).

Figure 2: Numerical distribution related to the publication year of selected articles. Santo André, 2015.

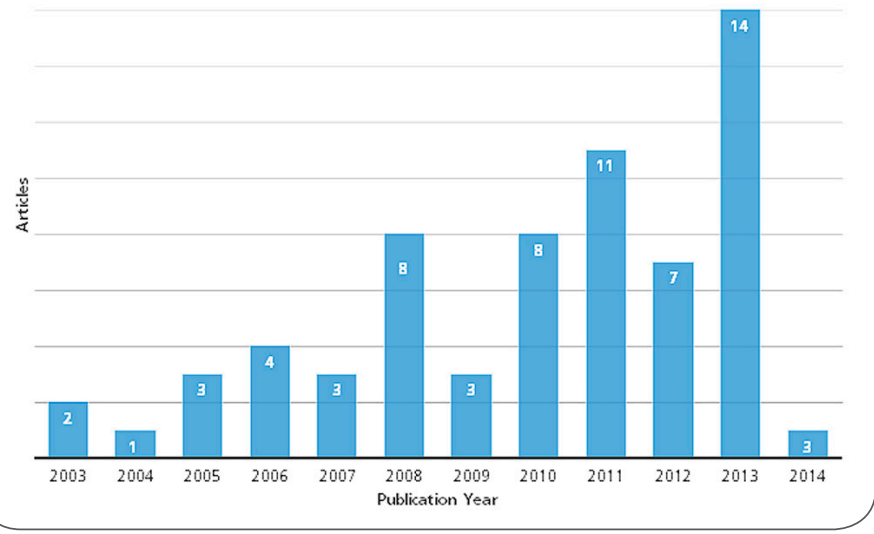

It's noticeable a publishing constant increase focusing the patient being, this fact justified by the health professional concern increase referring to the patient total well-being, as the suffer relief continues to be a challenge for palliative care teams, including those with more symptoms control experience. Spiritual and emotional aspects need inter-disciplinary team dedication [35]. Considering that in the last five years there has been an increase of $64,2 \%$ of scientific productions about the theme, so it opens a wide field for researches, with multiple experimental design perspectives to define repercussions of positive emotions from faith and spirituality during the palliative care process.

Once the evidenced scientific productions are characterized it was chosen to categorize in five groups: (1) Symptoms control (free of pain and physical symptoms); (2) Quality of life (psychological well-being, maintenance of proud and good family relationship); (3) Spirituality (faith, hope, trust, prayers); (4) Confronting (illness acceptance courage "acceptance", following the treatment, fear and life reassessment); (5) Cultural questions (race/ethnics and e demographic location). Through content analyses it was identified that some articles presented one or more categories. (Figure 3).

Figure 3: Distribution of periodicals by categories. Santo André, 2015.

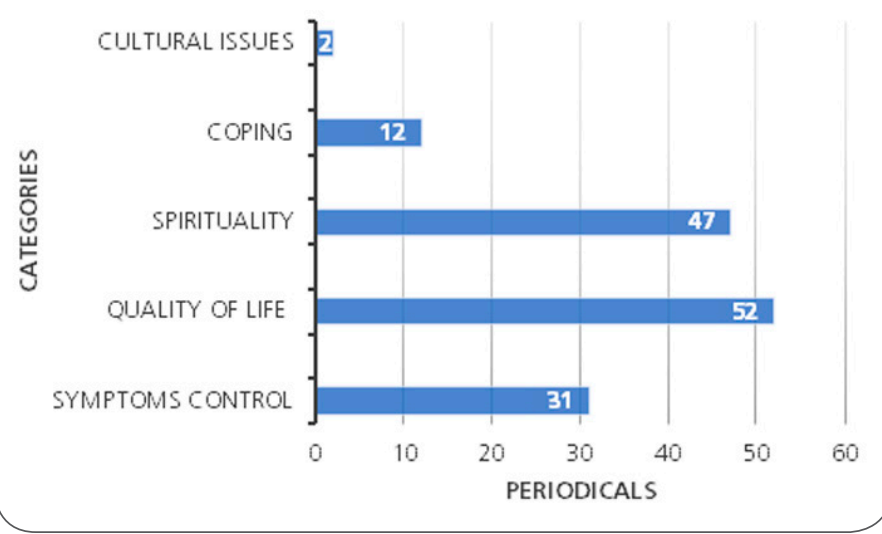


The search identified, among the 67 studies in this review that, $77,6 \%$ of them see the life quality categories a driving force for the palliative treatment followed by the spirituality category at $70,14 \%$. The spiritual intervention resulted in a significant increase of hope, happiness and life satisfaction $(P<0,05)$ [17]. The spirituality is one of the main aspects of palliative care. The concept is multidimensional and embraces existential sphere, as well as considerations based in religious values [46].

The symptoms control category ( $N=31=46,26 \%)$ are listed: bone pain, general pain, fatigue, appetite loss, somnolence, dry mouth, tachycardia, and memory disturbs as well as physical symptoms such as depression, anxiety, anguish, sadness, sexuality, faith loss as psychological symptons [19]. Correlating this category to spirituality, studies suggest that well-being is an important component in life quality of advanced cancer patients, and is inly related to physical and psychological symptoms of distress, which should be approached in a proper way in palliative care environment [19].

The confronting category ( $\mathrm{N}=12=17,91 \%)$ came up while analyzing that many studies brought up that the oncologic patient lived a reflection moment and needed a comprehension of the palliative care context and the sicken process in the moment that there aren't possibilities of cure but control and handling of the symptoms. This review found significant material of spirituality for these patients to face and adjust to this new situation. It's considered a quality of life aspect which mediates social, family and relationship improvement. [19]. The confronting moment is guided by Faith and hope, some authors bring faith, hope and trust as synonyms. In this period the patient is able to find spirituality and resilience, the individual becomes adaptable to the new clinical support allowing themselves to recover emotion balance after suffering from physical and psychological pain. In this phase they refer to the capability of wish restoration, recognizing their limitations and longing for a good death [19, 20, 23].
Studies show that young patients under 60 years old present more physical and psychological suffer and Faith loss. Young patients report difficulty to confront the decease for feeling deprived of autonomy and professional and personal achievement wish. In done studies with children under 12 years old their sickness confronting was reflected in the concern related to their parents and they used to pray for them to feel closer to God. Facing this, the involved therapies for this process have to be planned according to the age rate $[21,49]$.

Two studies have been identified approaching the cultural question category ( $\mathrm{N}=2=2,98 \%$ ), reflecting about promoting the comprehension of dignity and suffering reduction in the life end, in old patients with advanced cancer in the western. The method used to define the dignity concept in Chinese concept, the death anguish isn't appointed by relatives, they mention themes as resilience/ fighting spirit which is expressed in different ways in the Chinese Family context, resulting in a Family cultural dimension that assists the dignity building. The second study approached patients in Japan and six European countries including concepts which cover religious questions, which are clearly important for different populations with religious beliefs [23, 27].

Summarizing this study and recommending interventions in treatment was necessary to retake study about limbic system - the responsible for emotions: happiness, fear, anger, pleasure, and Faith. For this study, a central subjective and peripheral component was distinguished, the emotional behavior. The peripheral component is the way emotion expresses and involves somatic, motor and visceral activity standards, which are characteristic of each kind of species. The religious experiences are complex. They involve emotion and cognition and are distributed in various structures. They are connected to the frontal lobe, the brain part that controls desires; parietal lobe area, which controls our own sense; limbic system, which performs fundamental role in emotions; 
and, finally, hypothalamus, that is also responsible for emotive reactions $[7,80]$.

In psychiatry and its areas, the neural structure identification related to emotion, has a special interest in the human being behavior comprehension. Therefore, much has been discussed about the possibility of treating scientifically the questions related to emotion, and not only in the Philosophical scope. With the development of neuroscience, postulates that, as perception (afferent) and the action (efferent), the emotion is related to diverse brain circuits. Moreover, the emotions are generally followed by autonomic, endocrine and motor skeletal responses that depend on the subcortial area of the nervous system, which prepare the body for action. It's been learnt that emotions are result of multiple systems of body and brain distributed by the whole person, being impossible to split emotion from cognition neither cognition from body [81].

There is a consensus among many authors that the limbic system has as main structures: cortical gyri, core gray matter and white matter disposed in medial surfaces of both hemispheres and surrounding the third ventricle. These structures, functiona$\| y$, relate to instincts, emotions and memory and, through hypothalamus, as homeostasis maintaining $[80,82]$.

The "rewarding centre" is related, mainly, to medial forebrain bundle, in core and ventromedial sides of hypothalamus, having connections with septum, tonsil, some thalamus areas and basal ganglia. The "punishing centre" is described as located in the central gray area which surrounds the cerebral aqueduct of Sylvius, in the midbrain, reaching the zones [80].

The happiness induction, response to identification of facial expressions of happiness, to the visualization of pleasant images and/or to induction to happiness of memories, sexual pleasure and well succeed competitive stimulation, promotes the activation of basal ganglia, including the ventral striatum and the putamen [81, 82].
The sadness and depression can be seen as "poles" of the same process. The first is considered "physiological", and the second, "pathological", being, for this reason, related in neurophysiological terms. It's each time more often the correlation between emotional dysfunctions and damages of the neurocognitive functions. In fact, the depression is associated to deficits in strategic areas of the brain, including limbic areas. Regardless of related emotional factors, there are many biological determiners involved in its development; watching occurred changes in the immunological system $[80,82]$.

Therefore, the present study pointed a scientific contribution from faith and spirituality themes from anatomy knowledge of emotions understanding how the authors could work with the patient positive emotions from Faith and spirituality communication, such themes which permeated all worked categories in this study taking sometime to an improvement of physiologic and psychological symptoms, of social and immunological relations during the palliative treatment. Proposed actions by this review involve the communication of the team with the patient allied to an increase of life quality, therapy groups, focal therapy, religious presence for comfort and life reflection and about the moment that they are living, art therapy and music. Activities that promote pleasure as visualizing landscapes, photos that reminded good memories, stimulating the positive emotion centre.

\section{Conclusion}

The faith performs in diverse brain areas, mainly in the limbic system, that is responsible for emotions and, spirituality is the way the individual see himself as origin, religion and culture in which is inserted. The spiritual intervention seems to be a potential beneficial intervention to increase mental power among those who suffer from cancer in terminal phase [40]. The results suggest hormonal existing 
changes in immunological system and autonomous and central nervous systems, reducing heart beating, blood pressure and stress. A great amount of studies point that religiousness results in benefits to the health.

The oncologic patient in palliative care when acquires the self-knowledge and acceptance promoted by Faith can change habits, as improving diet, doing exercises that can promote pleasure, (arts, music, reading), having a restful sleep and maintain balance between thoughts and attitudes. The spirituality also helps to combat depression, as it attenuates bitterness feelings, anger, stress and even resentment. Therefore, it seems necessary to consider faith as an important element of treatment and palliative care.

According to studies involved in this review, the human factor is related directly to patient care, in special health team, needs to be capable of dealing with care concept about the patient faith and spirituality.

Still exist gaps of knowledge of the applicability of Faith and spirituality in these patients, there isn't consensus about the indication of proposed therapies along this review, being necessary additional researches focused on the training development for these professionals enabling them to deal with this fragile population which requires well applied therapeutics techniques and respecting their own individuality.

\section{References}

1. Brasil. Ministério da Saúde (BR). Instituto Nacional de Câncer José Alencar Gomes da Silva. ABC do câncer: abordagens básicas para o controle do câncer / 2 eds. rev. e atual. - Rio de Janeiro: Inca, 2012. 129 p.

2. Brasil. Ministério da Saúde. Secretaria de atenção à Saúde. Instituto Nacional do Câncer José Alencar Gomes da Silva. Estimativa 2014 -Incidência de Câncer no Brasil. [Acess in: 27 February 2015]. Available in: http://www2.inca.gov.br/ wps/wcm/connect/0129ba0041fbbc01aa4fee936e134226/ Apresentacao+Estimativa+2014_final+corrigido+tireoide.pd $\mathrm{f}$ ?MOD=AJPERES\&CACHEID=0129ba0041fbbc01aa4fee93 $6 \mathrm{e} 134226$
3. Brasil. Conselho Regional de Medicina do Estado de São Paulo (CREMESP). Cuidado Paliativo/Coordenação Institucional de Reinaldo Ayer de Oliveira. São Paulo: 2008, 16 p.

4. Freud S. A história do movimento psicanalítico, Artigos sobre metapsicologia e outros trabalhos. Luto e Melancolia. Vol. XIV. ed. Imago. Rio de Janeiro, 2006, p. 245-263.

5. Kübler-ross E. Sobre a morte e o morrer. São Paulo,Martins Fontes, 1996, p. 51-149.

6. Vaillant GE. Emoções positivas. In: Fé: Evidências Científicas. Barueri, SP. Ed. Manole, 2010, p.3-5

7. Veit CM, Castro EK. Coping religioso/espiritual e câncer de mama: Uma revisão sistemática da literatura. Psicologia, saúde \& doenças, 2013, 14(1), 1- 22.

8. WHO (World health Organization). National Cancer control Programmes: Policies and managerial guidelines world. 2002. [Acess 27 February 2015]. Available: http://www.who.int/ cancer/palliative/definition/en/

9. Canadian Palliative Care Association. Ferris FD, Cummings I, editors. Palliative care: Towards a consensus in standardized principles of practice. Ottawa, ON. 1995, p.12

10. Cochrane Collaboration. [Acesso em 20 de maio de 2014]. Disponível em: http://www.cochrane.dk/Cochrane/hbook.html.

11. Richardson WS, Wilson MC, Nishikawa J, et al. The well-buit clinical question: a key to evidence-based decisions. ACP Journal Club. 1995, 123: 12.

12. Stone P. Popping the (PICO) Question in Reseach and EvidenceBased Practice. Applied Nursing Research. 2002, 16(2): 197-8.

13. Rosenzweig MQ, Wiehagen T, Brufsky A, Arnold R. Challenges of illness in metastatic breast cancer: A low-income African American perspective. Palliative and Supportive Care 2009, 7 (2), p. 143-152

14. Koffman J, Morgan M, Edmonds P, Speck P, Higginson IJ. Cultural meanings of pain: A qualitative study of Black Caribbean and White British patients with advanced cancer. Palliative Medicine 2008, 22 (4), 350-359.

15. Fatone AM., Moadel AB, Foley FW, Fleming M, Jandorf L. Urban voices: The quality-of-life experience among women of color with breast cancer. Palliative and Supportive Care 2007, 5 (2), 115-125.

16. Hirai, K., Miyashita, M., Morita, T., Sanjo, M., Uchitomi, Y. Good Death in Japanese Cancer Care: A Qualitative Study. Journal of Pain and Symptom Management 2006, 31 (2), 140-147

17. Asgeirsdottir $G H$, Sigurbjörnsson $E$, Traustadottir $R$, Sigurdardotti V, Gunnarsdottir S, Kelly E. In the shadow of death: existential and spiritual concerns among persons receiving palliative care. The journal of pastoral care \& counseling : JPCC, 2014, 68 (1-2), 4.

18. King $M$, Llewellyn $H$, Leurent $B$, Owen $F$, Leavey $G$, Tookman A, Jones L. Spiritual beliefs near the end of life: A prospective cohort study of people with cancer receiving palliative care. Psycho-Oncology, 2013, 22 (11), 2505-2512. 
19. Douglas SL, Daly BJ. The impact of patient quality of life and spirituality upon caregiver depression for those with advanced cancer. Palliative and Supportive Care, 2013, 11 (5), 389-396.

20. Skeath $P$, Norris S, Katheria V, White J, Baker K., Handel D, Sternberg E, Pollack J, Groninger H, Phillips J, Berger A. The nature of life-transforming changes among cancer survivors. Qualitative Health Research, 2013, 23 (9), 1155-1167.

21. Yang $\mathrm{CH}$, ChiuYW, Huang, CT, Haung YW, Chuang HY. A comprehensive approach in hospice shared care in Taiwan: Nonelderly patients have more physical, psychosocial and spiritual suffering. Kaohsiung Journal of Medical Sciences, 2013, 29 (8), 444-450.

22. Wong E, Chow E, Zhang L, Bedard G, Lam K., Fairchild A, Vassiliou V, Alm El-Din MA, Jesus GR, Kumar A, Forges F, Tseng LM, Hou MF, Chie WC, Bottomley A. Factors influencing health related quality of life in cancer patients with bone metastases. Journal of Palliative Medicine, 2013, 16 (8), 915-921.

23. Ho AHY, Chan CLW, Leung PPY, Chochinov HM, Neimeyer RA, Pang SMC, Tse DMW. Living and dying with dignity in Chinese society: Perspectives of older palliative care patients in Hong Kong. Age and Ageing, 2013, 42 (4), 455-461.

24. Balboni TA, Balboni M, Enzinger AC, Gallivan K, Paulk ME, Wright A, Steinhauser K, VanderWeele TJ, Prigerson HG. Provision of spiritual support to patients with advanced cancer by religious communities and associations with medical care at the end of life. JAMA Internal Medicine, 2013, 173 (12), 11091117.

25. Asgeirsdottir GH, Sigurbjörnsson E, Traustadottir R, Sigurdardottir V, Gunnarsdottir S, Kelly E. "To Cherish Each Day as it Comes": A qualitative study of spirituality among persons receiving palliative care. Supportive Care in Cancer, 2013, 21 (5), 1445-1451.

26. Keall RM, Butow PN, Steinhauser KE, Clayton JM. Nursefacilitated preparation and life completion interventions are acceptable and feasible in the australian palliative care setting: Results from a phase 2 trial. Cancer Nursing, 2013, 36 (3), 3946

27. Vivat B, Young T, Efficace F, Siguradóttir V, Arraras Jl., Åsgeirsdóttir GH, Brédart A, Costantini A, Kobayashi K, Singer S. Cross-cultural development of the EORTC QLQ-SWB36: A stand-alone measure of spiritual wellbeing for palliative care patients with cancer. Palliative Medicine, 2013, 27 (5), 457-469.

28. Nakau M, Imanishi J, Imanishi J, Watanabe S, Imanishi A, Baba T, Hirai K, Ito T, Chiba W, Morimoto Y. Spiritual care of cancer patients by integrated medicine in urban green space: A pilot study. The Journal of Science and Healing, 2013, 9 (2), 87-90.

29. Balboni MJ, Sullivan A, Amobi A, VanderWeele TJ, Balboni TA. Why is spiritual care infrequent at the end of life? spiritual care perceptions among patients, nurses, and physicians and the role of training. J Clin Oncol, 2013, 31: 461-467.
30. Rawdin B, Evans C, Rabow MW. The relationships among hope, pain, psychological distress, and spiritual well-being in oncology outpatients. Journal of Palliative Medicine, 2013, 16 (2), 167172.

31. Abu-Saad Huijer H, Sagherian K, Tamim H, Naifeh KM, Abboud MR. Quality of palliative care in children with cancer in Lebanon. Journal Medical Libanais, 2013,61 (4),228-236.

32. Ho CT, Hsu HS, Li Cl, Liu CS, Lin CY, Lin CC, Lin WY. Certain biopsychosocial-spiritual problems associated with dyspnea among advanced cancer patients in Taiwan. Supportive Care in Cancer, 2012, 20 (8), 1763-1770.

33. Samuelson BT, Fromme EK, Thomas CR. Changes in Spirituality and Quality of Life in Patients Undergoing Radiation Therapy. American Journal of Hospice and Palliative Medicine, 2012, 29 (6), 449-454.

34. McClean, S., Bunt, L., Daykin, N. The healing and spiritual properties of music therapy at a cancer care center. Journal of Alternative and Complementary Medicine, 2012, 18 (4), 402407.

35. Kang J, Shin DW, Choi JY, Park CH, Baek YJ, Mo HN, Song $\mathrm{MO}$, Park SA, Moon DH, Son KY. Addressing the religious and spiritual needs of dying patients by healthcare staff in Korea: Patient perspectives in a multi-religious Asian country PsychoOncology, 2012, 21 (4), 374-381.

36. Spencer RJ, Ray A, Pirl WF, Prigerson HG. Clinical correlates of suicidal thoughts in patients with advanced cancer. American Journal of Geriatric Psychiatry, 2012, 20 (4), 327-336.

37. Vallurupalli M, Lauderdale K, Balboni MJ, Phelps AC, Block SD, $\mathrm{Ng}$ AK, Kachnic LA, VanderWeele TJ, Balboni TA. The Role of Spirituality and Religious Coping in the Quality of Life of Patients With Advanced Cancer Receiving Palliative Radiation Therapy. Journal of Supportive Oncology, 2012, 10 (2), 81-87.

38. Balboni T, Balboni M, Paulk ME, Phelps A, Wright A, Peteet J, Block S, Lathan C, Vanderweele T, Prigerson H. Support of cancer patients' spiritual needs and associations with medical care costs at the end of life. Cancer, 2011, 117 (23), 5383-5391.

39. Winkelman WD, Lauderdale K, Balboni MJ, Phelps AC, Peteet JR, Block SD, Kachnic LA, VanderWeele TJ, Balboni TA. The relationship of spiritual concerns to the quality of life of advanced cancer patients: Preliminary findings. Journal of Palliative Medicine, 2011, 14 (9), 1022-1028.

40. Fallah R, Golzari M, Dastani M, Akbari ME. Integrating spirituality into a group psychotherapy program for women surviving from breast cancer. Iranian Journal of Cancer Prevention, 2011, 4 (3), 142-148.

41. Trinkaus M, Burman D, Barmala N, Rodin G, Jones J, Lo C, Zimmermann C. Spirituality and use of complementary therapies for cure in advanced cancer. Psycho-Oncology, 2011, 20 (7), 746-754 
42. Delgado-Guay MO, Hui D, Parsons HA, Govan K, De La Cruz M, Thorney S, Bruera E. Spirituality, religiosity, and spiritual pain in advanced cancer patients. Journal of Pain and Symptom Management, 2011, 41 (6), 986-994.

43. Hui D, De La Cruz M, Thorney S, Parsons HA, Delgado-Guay $\mathrm{M}$, Bruera $\mathrm{E}$. The frequency and correlates of spiritual distress among patients with advanced cancer admitted to an acute palliative care unit. American Journal of Hospice and Palliative Medicine, 2011, 28 (4), 264-270.

44. Balboni MJ, Babar A, Dillinger J, Phelps AC, George E, Block SD, Kachnic L, Hunt J, Peteet J, Prigerson HG, Vanderweele TJ, Balboni TA. "It depends": Viewpoints of patients, physicians, and nurses on patient-practitioner prayer in the setting of advanced cancer. Journal of Pain and Symptom Management, 2011, 41 (5), 836-847.

45. Bergman J, Fink A, Kwan L, Maliski S, Litwin MS. Spirituality and end-of-life care in disadvantaged men dying of prostate cancer. World Journal of Urology, 2011,29 (1), 43-49.

46. Kandasamy A, Chaturved SK, Desai G. Spirituality, distress, depression, anxiety, and quality of life in patients with advanced cancer. Indian Journal of Cancer, 2011, 48 (1), 55-59.

47. Leung KK, Tsai JS, Cheng SY, Liu WJ, Chiu TY, Wu CH, Chen CY. Can a good death and quality of life be achieved for patients with terminal cancer in a palliative care unit? Journal of Palliative Medicine, 2010, 13 (12), 1433-1438.

48. Pituskin E, Fairchild A, Dutka J, Gagnon L, Driga A, Tachynski $P_{\text {, }}$ Borschneck JA, Ghosh S. Multidisciplinary team contributions within a dedicated outpatient palliative radiotherapy clinic: A prospective descriptive study. International Journal of Radiation Oncology Biology Physics, 2010, 78 (2), 527-532.

49. Kamper R, Van Cleve L, Savedra M. Children With Advanced Cancer: Responses to a Spiritual Quality of Life Interview. Journal for Specialists in Pediatric Nursing, 2010, 15 (4), 301-306.

50. Mishra S, Bhatnagar S, Philip FA, Singhal V, Rana SPS, Upadhyay SP, Chauhan G. Psychosocial concerns in patients with advanced cancer: An observational study at regional cancer centre, India. American Journal of Hospice and Palliative Medicine, 2010, 27 (5), 316-319.

51. Collette N, Pascual A. Two case histories of suffering treated with art therapy: A symbolic, spiritual approach [Dos casos de sufrimiento tratados con arteterapia: Una aproximación simbólica y espiritual]. Medicina Paliativa, 2010, 17 (4), 196-200.

52. Breitbart W, Rosenfeld B, Gibson C, Pessin H, Poppito S, Nelson C, Tomarken A, Timm AK, Berg A, Jacobson C, Sorger B, Abbey J, Olden M. Meaning-centered group psychotherapy for patients with advanced cancer: A pilot randomized controlled trial. Psycho-Oncology, 2010, 19 (1), 21-28.

53. Rinaldis M, Pakenham KI, Lynch BM, Aitken JF. Development, confirmation, and validation of a measure of Coping with Colorectal Cancer: A longitudinal investigation. PsychoOncology, 2009, 18 (6), 624-633.
54. Rodin G, Lo C, Mikulincer M, Donner A, Gagliese L, Zimmermann C. Pathways to distress: The multiple determinants of depression, hopelessness, and the desire for hastened death in metastatic cancer patients. Social Science and Medicine, 2009, 68 (3), 562569.

55. Mystakidou K, Tsilika E, Prapa E, Smyrnioti M, Pagoropoulou A, Lambros V. Predictors of spirituality at the end of life. Canadian Family Physician, 2008, 54 (12), 1720-1721.

56. Steinhauser KE, Alexander SC, Byock IR, George LK, Olsen MK, Tulsky JA. Do preparation and life completion discussions improve functioning and quality of life in seriously ill patients? Pilot randomized control trial. Journal of Palliative Medicine, 2008, 11 (9), 1234-1240.

57. Reynolds MAH. Hope in adults, ages 20-59, with advanced stage cancer. Palliative and Supportive Care, 2008, 6 (3), 259264.

58. Koffman J, Morgan M, Edmonds P, Speck P, Higginson IJ. "I know he controls cancer": The meanings of religion among Black Caribbean and White British patients with advanced cancer. Social Science and Medicine, 2008, 67 (5), 780-789.

59. Mystakidou K, Tsilika E, Parpa E, Hatzipli I, Smyrnioti M, Galanos A, Vlahos L. Demographic and clinical predictors of spirituality in advanced cancer patients: A randomized control study. Journal of Clinical Nursing, 2008, 17 (13), 1779-1785.

60. Wijk H, Grimby A. Needs of elderly patients in palliative care. American Journal of Hospice and Palliative Medicine, 2008, 106-111.

61. Ando M, Tsuda A, Morita T. Life review interviews on the spiritual well-being of terminally ill cancer patients. Supportive Care in Cancer, 2007, 15 (2), 225-231

62. Mystakidou K, Tsilika E, Parpa E, Smyrnioti M, Vlahos L. Assessing spirituality and religiousness in advanced cancer patients. American Journal of Hospice and Palliative Medicine, 2006, 23 (6), 457-463.

63. Mako C, Galek K, Poppito SR. Spiritual pain among patients with advanced cancer in palliative care. Journal of Palliative Medicine, 2006, 9 (5), 1106-1113.

64. Renz M., Schütt M, Cerny T. Spirituality, psychotherapy and music in palliative cancer care: Research projects in psychooncology at an oncology center in Switzerland. Supportive Care in Cancer, 2005, 13 (12), 961-966.

65. McClain-Jacobson C, Rosenfeld B, Kosinski A, Pessin H, Cimino JE, Breitbart W. Belief in an afterlife, spiritual well-being and end-of-life despair in patients with advanced cancer. General Hospital Psychiatry, 2004, 26 (6), 484-486.

66. Kawa M, Kayama M, Maeyama E, Iba N, Murata H, Imamura $Y$, Koyama T, Mizuno M. Distress of inpatients with terminal cancer in Japanese palliative care units: From the viewpoint of spirituality. Supportive Care in Cancer, 2003, 11 (7), 481490. 
67. McClain, C.S., Rosenfeld, B., Breitbart, W. Effect of spiritual well-being on end-of-life despair in terminally-ill cancer patients. Lancet, 2003, 361 (9369), 1603-1607.

68. Osborne TR, Ramsenthaler C, de Wolf-Linder S, Schey SA, Siegert RJ, Edmonds PM, Higginson IJ. Understanding what matters most to people with multiple myeloma: a qualitative study of views on quality of life. BMC Cancer. 2014, 9; 14: 496.

69. Vilalta A, Valls J, Porta J, Viñas J. Evaluation of spiritual needs of patients with advanced cancer in a palliative care unit. J Palliat Med. 2014, 17(5): 592-600.

70. Trevino KM, Archambault E, Schuster JL, Hilgeman MM, Moye J. Religiosity and spirituality in military veteran cancer survivors: a qualitative perspective. J Psychosoc Oncol. 2011, 29(6): 619-35.

71. Rose JH, Kypriotakis G, Bowman KF, Einstadter D, O'Toole EE, Mechekano R, Dawson NV. Patterns of adaptation in patients living long term with advanced cancer. Cancer. 2009, 15;115(18 Suppl): 4298-310.

72. Alcorn SR, Balboni MJ, Prigerson HG, Reynolds A, Phelps AC, Wright AA, Block SD, Peteet JR, Kachnic LA, Balboni TA. "If God wanted me yesterday, I wouldn't be here today": religious and spiritual themes in patients' experiences of advanced cancer. J Palliat Med. 2010, 13(5): 581-8.

73. Mystakidou K, Tsilika E, Parpa E, Pathiaki M, Patiraki E, Galanos A, Vlahos L. Exploring the relationships between depression, hopelessness, cognitive status, pain, and spirituality in patients with advanced cancer. Arch Psychiatr Nurs. 2007, 21(3): 150-61.

74. Noguchi W, Morita S, Ohno T, Aihara O, Tsujii H, Shimozuma $\mathrm{K}$, Matsushima E. Spiritual needs in cancer patients and spiritual care based on logotherapy. Support Care Cancer. 2006, 14(1): 65-70.

75. Luhrs CA, Meghani S, Homel P, Drayton M, O'Toole E, Paccione M, Daratsos L, Wollner D, Bookbinder M. Pilot of a pathway to improve the care of imminently dying oncology inpatients in a Veterans Affairs Medical Center. J Pain Symptom Manage. 2005, 29(6): 544-51.

76. Paiva CE, Paiva BS, de Castro RA, Souza Cde P, de Paiva Maia YC, Ayres JA, Michelin OC. A pilot study addressing the impact of religious practice on quality of life of breast cancer patients during chemotherapy. J Relig Health. 2013 Mar;52(1): 184-93.

77. McConigley R, Holloway K, Smith J, Halkett G, Keyser J, Aoun $\mathrm{S}$, Monterosso L. The diagnosis and treatment decisions of cancer patients in rural Western Australia. Cancer Nurs. 2011 Jul-Aug;34(4): 1-9.

78. Utne I, Miaskowski C, Bjordal K, Paul SM, Jakobsen G, Rustøen $T$. The relationship between hope and pain in a sample of hospitalized oncology patients. Palliat Support Care, 2008, 6(4): 327-34.

79. Sharf BF, Stelljes LA, Gordon HS. 'A little bitty spot and I'm a big man': patients' perspectives on refusing diagnosis or treatment for lung cancer. Psychooncology, 2005, 14(8): 636-46.
80. Machado ABM. Áreas Encefálicas Relacionadas com as Emoções. O Sistema Límbico. In: Neuroanatomia Funcional. São Paulo. Editora Atheneu, $2^{a}$ edição, ano 2000, 28: 275-86.

81. Barreto JEF, Silva LP. Sistema límbico e as emoções - uma revisão anatômica. Rev Neurocienc, 2010, 18(3): 386-394.

82. Salzman CD, Fusi S. Emotion, Cognition, and Mental State Representation in Amygdala and Prefrontal Cortex. Annu Rev. Neurosci, 2010, 33: 173-202.

\section{Comment on this article:}

\section{(f) in $8+\mathbf{S} P$}

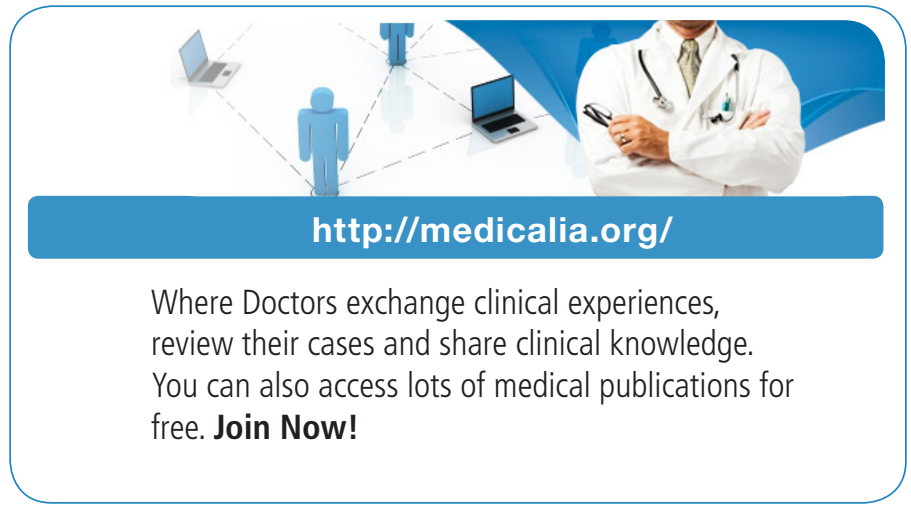

\section{Publish with iMedPub}

\section{http://www.imed.pub}

International Archives of Medicine is an open access journal publishing articles encompassing all aspects of medical science and clinical practice. IAM is considered a megajournal with independent sections on all areas of medicine. IAM is a really international journal with authors and board members from all around the world. The journal is widely indexed and classified Q1 in category Medicine. 